\title{
WestVirginiaUniversity.
}

Department of Economics

Working Paper Series

\section{Economies of Scale and Governance of Library Systems: Evidence from West Virginia}

Amir B. Ferreira Neto

Joshua Hall

Working Paper No. 17-13

This paper can be found at the College of Business and Economics Working Paper Series homepage: 


\title{
Economies of Scale and Governance of Library Systems: Evidence from West Virginia
}

\author{
Amir B. Ferreira Neto ${ }^{1}$ and Joshua Hall ${ }^{1}$ \\ ${ }^{1}$ West Virginia University
}

June 6, 2017

\begin{abstract}
Public libraries are a billion dollar industry in the United States. We explore the institutional determinants of public library technical efficiency using data from West Virginia. We first document considerable cross-district variation in library efficiency. While the average library district in our sample is between $81 \%$ and $90 \%$ efficient depending upon the year and measure, there are many districtyears that are under $50 \%$. We then explain our technical efficiency measures as a function of institutional variables reflecting the type of district and sources of funding. We find consistent evidence that urban libraries are more inefficient, perhaps because they are too small to achieve sufficient economies-of-scale in production of library services. In addition, we find revenue from local sources is associated with reduced efficiency, contrary to what would be predicted by local public goods producer theory.
\end{abstract}

Keywords: Data Envelopment Analysis, Efficiency, Government, Public Libraries

JEL Classification: H41, H76, I29 


\section{Introduction}

Education is an important part of publicly-provided services in both urban and rural areas, and public libraries can be a large part of community and K-12 education (Collins and Halverson, 2010). For example, in an important recent paper, Bhatt (2010) finds that library attendance of school children increases their time spent reading at home and positively impacts their homework completion rate. In addition, urban and rural communities value libraries in ways that are not captured in usage statistics as evidenced by contingent valuation studies (Aabø, 2005; Aabøand Strand, 2004; McCallum and Quinn, 2004).

The American Library Association (2015) estimates that there are over nine thousand public libraries in the United States, representing nearly $8 \%$ of the total number of libraries in the country. According to the Institute of Museums and Library Services (IMLS, 2013a) there were over 1.5 billion in-person visits to public libraries in 2012 alone. The IMLS (2013b) reported that in 2012 public libraries had revenues of $\$ 11.5$ billion, $84.4 \%$ from local government sources, $6.9 \%$ from state sources, and less than $1 \%$ from the federal government. Across states, however, there is considerable variation. In West Virginia, for example, the state average local operating revenue per capita was $\$ 13.04$ compared to a national average of $\$ 32.31$ in the 2012 fiscal year.

The benefits of public libraries do come with costs, however, and Aabøand Strand (2004) highlights the recent pressures on public library budgets given other demands such as health care. As reported by Aabøand Strand (2004) and several others ${ }^{1}$ local governments have been cutting public library funding, resulting in library branch closures and/or reduced hours. In response, some localities have passed special local levies to provide more funding to public libraries to restore cut or reduced services. West Virginia is an interesting case as 11 counties have special laws to fund public libraries. Since 2014 there have been at least two new levies placed on the ballot that have passed. ${ }^{2}$

We have two primary aims in this paper. The first is to evaluate the efficiency of West Virginia public library systems. Given ongoing strains in public budgets in West Virginia (and other states), it is important to know whether public funds are being used efficiently. Second, after finding variation in technical efficiency (TE) across public library districts, we use our measures of TE to test whether the source of funding matters for efficiency. Hoxby (1999) provides reasons why local property tax-based finance can improve the productivity of local public good producers. Hall (2007) finds that Ohio school districts with a greater share of funding from local sources have higher scores on state exams. Additionally, people are concerned with the size of government and if their tax money is being allocated properly. Similar looks at the sources of public sector efficiency include Afonso et al. (2005), Smith and Street (2005), Afonso and Aubyn (2005), and Detotto and McCannon (2017).

In looking at the technical efficiency of libraries we follow in the footsteps of a

\footnotetext{
${ }^{1}$ Blau (2011), Warburton (2013), Smith (2015), Kelley (2015), Davis (2015), Stepleton (2015), Woods (2015) and Cleaver (2015) are non exhaustive examples.

${ }^{2}$ Willes (2016) and Gazette (2016).
} 
number of papers, each focusing on a different region. For example, Worthington (1999) assesses the efficiency of local government libraries in Australia, Hammond (2002, 2009) analyzes libraries in the of United Kingdom, and Witte and Geys (2011) studied all municipal public libraries in Flanders, Belgium. In United States, there are a handful of papers (Vitaliano, 1997, 1998; Sharma et al., 1999; Hemmeter, 2006). Vitaliano (1997) looks at the state of New York state using a stochastic frontier model and finds that public libraries are 3\% more inefficient than not-for-profit libraries. Vitaliano (1998) uses Data Envelopment Analysis (DEA) on 184 libraries - also in New York - and finds that libraries could reduce their inputs by one-third without compromising output. Sharma et al. (1999) evaluates 47 libraries in Hawaii for one fiscal year using DEA and find that the average technical efficiency is 0.84 with a range of 0.45 to 1 . As for Hemmeter (2006), the author analyzes the cost-efficiency of nearly all public libraries in the United States using a stochastic cost frontier and finds that inefficiency in smaller libraries is decreased with local government spending. ${ }^{3}$

We follow Vitaliano (1998) and Hammond (2002) and estimate the technical efficiency of public libraries in West Virginia using Data Envelopment Analysis (DEA). After estimating the technical efficiency of West Virginia libraries, we look at the institutional determinants of library efficiency in the state. Our results show that for West Virginia, local (that is, non-county or multi-jurisdictional) libraries have lower levels of technical efficiency, suggesting an inability to take advantage of economiesof-scale. We also find a negative relationship between local support and technical efficiency, contrary to what the work of Hoxby (1999) and Hall (2007) suggest would be the case. These results are robust across different specifications and are important to voters, policymakers, and scholars of government efficiency.

\section{Empirical Strategy}

\subsection{The Public Library Survey}

To analyze the efficiency of public libraries and revenues from government, we use the Public Libraries Survey (PLS). This dataset is collected annually since 1988 and covers all 50 states, the District of Columbia and outlying territories. The survey has a $98 \%$ response rate and is the closest thing to a complete census of public library systems in the United States (IMLS 2013a). The PLS survey provides information for each library system on features such as location, attendance, staffing, revenues by source, salaries paid, collection expenditures, collection, circulation, etc.

We employ a balanced panel of libraries from 2004 to 2013 for the state of West Virginia (WV). We chose this period of time because of data consistency with respect to the inputs and outputs used to estimate library technical efficiency (TE). Table 1 presents descriptive statistics used throughout our analysis by governance. Panel A shows the statistics for libraries run by municipal government; Panel B, those

\footnotetext{
${ }^{3}$ One reason to look within states, like we do with West Virginia, is that technical efficiency is a relative measure and the institutional constraints and funding methods vary so much across political jurisdictions that comparing Hawaii to West Virginia can be problematic.
} 
governed by county; and Panel C, the multi-jurisdictional ones. This is a first step to notice differences between libraries.

\subsection{Measuring Technical Efficiency}

The technical efficiency of a library is calculated using DEA. According to Bogetoft and Otto (2010), DEA analysis deals with two problems: estimating the standard and evaluating achievements against such determined standard. In this study we assume the Farrel notion of efficiency. Farrel efficiency is measured by minimizing inputs to reach the same level of output. Or conversely, by maximizing output given the current levels of inputs. The basic assumptions in the model are: free disposal, convexity and some determined return of scale.

Following Bogetoft and Otto (2010), define $x^{k}$ as the vector of $m$ inputs used and $y^{k}$ the $n$ outputs produced by firm $k$. TE can be calculated as:

$$
\begin{gathered}
T E_{k}=\min _{E, \lambda^{1}, \ldots, \lambda^{K}} E \\
\text { subject to: } \\
E x_{i}^{o} \geq \sum_{k=1}^{K} \lambda^{k} x_{i}^{k}, \quad i=1, \ldots, m \\
y^{o} \leq \sum_{k=1}^{K} \lambda^{k} y_{j}^{k}, \quad j=1, \ldots, n \\
\lambda \in \Lambda^{K}(\gamma) \quad(\text { iii })
\end{gathered}
$$

where $o$ refers to the standard firm, $\lambda$ is the parameter set, and $\gamma$ is an indicator of the return of scale. For more details, refer to Bogetoft and Otto (2010).

Note that as the DEA is a non-parametric technique, thus, there is no requirement of assuming a specific production function. Moreover, by changing constraint (iii) it is possible to test whether the firm is operating in a decreasing or increasing return to scale area. By solving the system above for each firm, we obtain a number that reflects, geometrically, the distance of each firm to the production frontier. Hence, the values of each TE measure will be bounded between zero and one, and are relative measures of efficiency. The higher the TE, the closer the firm is from the PPF and thus more efficient. To calculate TE, we use the package "Benchmarking" in $\mathrm{R}$ described by Bogetoft and Otto (2010).

We employ a variable returns to scale set-up. ${ }^{4}$ We use as inputs books, computers, librarians and total operational expenditure. Our measures of library output are the number of customer visits, hours opened, circulation, and number of programs provided to the community.

Instead of estimating the level of efficiency over the entire panel, we calculate TE for each year. This also allows us to measure and control for changes in efficiency of each library across time. Table 2 has the inputs and outputs used to estimate the TE of each library through DEA. Panel A show the inputs and Panel B the outputs. Both take into account the population served by the library, which allows for us to control for density and possible congestion in use.

\footnotetext{
${ }^{4}$ We also calculate the TE using a constant return to scale assumption, and use it to identify the libraries operating under increasing returns to scale. It is interesting that no library operates under decreasing returns to scale.
} 


\subsection{Technical Efficiency Results for West Virginia Libraries}

Table 3 presents summary statistics for our TE results. Panel A has the overall results, Panel B focuses on the legal basis of the library, i.e., the governance of the library, and Panel C summarizes by year. WV has three general types of governing authorities for libraries: city (CI), county (CO), and multi-jurisdictional (MJ). WV code requires public libraries that receive state aid to be governed by a local authority such as a city, county, county board of education, or a combination of jurisdictions. ${ }^{5}$ By looking at these results, it is possible to have an idea of which type of public libraries are the most efficient and how efficiency changes over time.

In Table 3 we can see in Panel B that library systems controlled by more than one governing body are relatively more efficient than those managed by a single one. Libraries governed by county officials are relatively more efficient than those run by cities. Panel C shows that TE increased between 2004 and 2010 when it flattened out. Appendix 1 shows the average TE and governance type for each library in the state of West Virginia over our sample.

\section{Explaining Technical Efficiency}

Allocative efficiency is an important topic in the public finance literature and for policymakers and citizens given current budget constraints. The case of public libraries in West Virginia is of special interest. State and local governments have been facing severe fiscal problems as the coal industry, the main driver of local government revenues, has declined over the past decade. The state also allows library to receive funds from local governments through special laws that in some cases date back to the 1930s. Moreover, special library levies have been placed onto local ballots in recent years and passed, suggesting the median voter in some communities desire more library output. In order to better understand the institutional determinants of TE in $\mathrm{WV}$, we regress the technical efficiency on the revenue from different sources and the legal base of the library system. Formally we have:

$$
T E_{i c t}=\alpha \operatorname{Rev}_{i c t}+\beta \operatorname{Gov}_{i t}+\gamma X_{i c t}+\mu_{c}+\delta_{t}+\epsilon_{i c t}
$$

where $T E_{i c t}$ is the technical efficiency of library system $i$, in county $c$, in year $t ; \operatorname{Rev}$ is the vector of revenue from local, state and federal governments, Gov is the vector of dummy variables for governance of each library system, $X$ is a vector of control variables such as existence of branches, if the library is operating under increasing returns to scale, and unemployment rate; $\mu_{c}$ is county fixed effect, and $\delta_{t}$ year fixed effect. The government revenue is in million dollars of 2000. We do not include other demographic characteristics such as percent married or gender by county as there is little to no variation in other demographics over this time period.

\footnotetext{
${ }^{5}$ West Virginia Library Commission (2013) lists seven different types of public library governing authorities. We count anything that is not a county commission or a municipality as multijurisdictional. For example, the six joint County/Municipality library systems are counted as multijurisdictional, as are the nine Board of Education/County/Municipality governed library systems.
} 
Our primary variables of interests are those related to governance structure and the level and source of funding. Following Hoxby (1999) and Hall (2007) we expect local spending to be positively related to TE. We include both the dollar amount of local spending and the percentage from local sources in our analysis. We do not have strong priors with respect to governance structure, although the work of Ostrom et al. (1961) suggests that cities and multi-jurisdictional governments might be more efficient as they might be more "organic" than county governance. We also include a binary variable for whether or not the library district had a special law passed by the state legislature that gives it dedicated local funding from the property tax. ${ }^{6}$ Table 4 provides summary statistics of the control variables used in the econometric analysis.

As previously discussed, we are interested in two set of results. Primarily, we want to know if public libraries governed by local authorities are relatively more efficient than others. Then we want to test if governments are investing in efficient libraries, which in turn suggests that they favor voters and their demand for more types of public goods. Hence, this section will at first focus on two sets of variables: the dummies of governance and the proportion of public spending by level of government.

Our baseline empirical results are presented in Table $5 .^{7}$ Column 1 has the results estimated using Ordinary Least Squares (OLS) with no year and county fixed effects. Column 2 includes country and year fixed effects, while Column 3 estimates the model using Weighted Least Squares (WLS) with income per capita used as the weight. The WLS estimates also include county and year fixed effects. The other control variables (branches, unemployment rate, and a dummy variable for increasing returns to scale library systems) are included but not reported. County governments are the excluded type of jurisdiction, thus city and multi-jurisdictional should be interpreted as in reference to county libraries.

Looking at our results, the first thing that is apparent is that contrary to our priors we find that the percentage of revenue from local sources is not related to TE in a statistically significant way. With respect to raw funding, we find consistent evidence across all three specifications that libraries receiving more local funding (in dollars) is negatively associated with TE. The opposite is true for state funding. Our empirical approach does not allow us to speak to causality on the spending/technical efficiency relationship. It could be that higher levels of state spending lead to public libraries being more technically efficient. We cannot, however, rule out reverse causality. Our results could reflect that more technically efficient libraries are more likely to receive state funding. Similarly we cannot rule out that technically inefficient public libraries are more likely to garner higher levels of local financial support.

Turning to our governance variables, we find across all three estimations that compared to library systems that are governed by county governments, city governments appear to be negatively related to TE. Depending on the specification, a city governed library is between 1.1 and 2.5 percentage points less technically efficient, ceteris paribus. We find no statistically significant results for multi-jurisdictional libraries.

\footnotetext{
${ }^{6}$ For more on these special laws, see West Virginia Library Commission (2013).

${ }^{7}$ We have also done the same analysis while not taking population into account when calculating TE. The results are robust and available upon request.
} 
Finally, libraries with special funding laws that guarantee them local revenue are negatively related to technical efficiency in all specifications. While it is possible that these laws are lowering TE, perhaps because the guaranteed funding makes library officials less concerned with satisfying voters, we cannot rule out reverse causality. It is possible that that libraries with low TE are more likely to need to pass special funding laws. ${ }^{8}$

One concern about our results in Table 5 is that our dependent variable is bounded between 0 and 1 and therefore the normality assumption of OLS is not valid. To deal with this issue we employ the fractional logit method with and without county and year fixed effects. These results are presented in Table 6. Both columns show the same specifications as in Table 5, with Column FL1 excluding county and year fixed effects and Column FL2 including them. The results corroborate our previous analysis showing a negative and statistically significant relationship between local funding and efficiency and a negative and statistically significant relation with city governance of libraries as well. Unlike in our OLS and WLS regressions, however, we find special laws to be statistically insignificant when year and county fixed effects are not included, contrary to the consistently negative results in Table 5. Libraries governed by multiple jurisdictions, however, are negative and statistically significant once county and year fixed effects are included.

\section{Discussion and Implications}

The objectives of this paper were to evaluate public library efficiency in West Virginia and to see if there was a relationship between government spending and TE. Using data from the PLS from 2004 to 2013, we calculated a TE measure using DEA and then regressed on data of government revenue for each library. Moreover, we are able to look at the role that the governing body of public libraries paid with respect to efficiency.

While not causal, the results suggest that libraries governed by cities are less efficient than those governed by counties or multiple jurisdictions. This may be because city library systems are too small to achieve the economies-of-scale exhibited by the county and multi-jurisdictional libraries. ${ }^{9}$ The relative efficiency of county systems is interesting in light of the work of Fischel (2010), who argues there may be gains when school districts and library systems are congruent, as synchronization of programs would be easier. In West Virginia, all school districts are county districts. One reason for county libraries as being more efficient might be greater synchronization with county school districts. Further research is clearly needed on this point as well as trying to tease out the causal direction of these associations.

Finally, our results with respect to local funding were the opposite of what was predicted by the literature on the efficiency of local public good provision. While we

\footnotetext{
${ }^{8}$ The fact that many of these laws were passed in the 1930s, however, is strong evidence against reverse causality.

${ }^{9}$ All city libraries are, by definition, smaller in area - but maybe not population - than county or multi-jurisdictional libraries.
} 
do not find strongly consistent evidence, it does not appear that libraries where more funding comes from local sources are more technically efficient. Given the increasing use of local levies to fund libraries in West Virginia, this finding has important public policy implications for library funding in the state moving forward.

\section{References}

Aabø, S. (2005). Valuing the benefits of public libraries. Information Economics and Policy, 17(2):175-198.

Aabø, S. and Strand, J. (2004). Public library valuation, nonuse values, and altruistic motivations. Library and Information Science Research, 26:351-372.

Afonso, A. and Aubyn, M. S. (2005). Non-parametric approaches to education and health efficiency in OECD countries. Journal of Applied Economics, 8(2):227-246.

Afonso, A., Schuknecht, L., and Tanzi, V. (2005). Public sector efficiency: An international comparison. Public Choice, 123(3):321-347.

American Library Association (2015). http://www.ala.org/tools/... libfactsheets/alalibraryfactsheet01. Accessed on September 20, 2015.

Bhatt, R. (2010). The impact of public library use on reading, television, and academic outcomes. Journal of Urban Economics, 68(2):148 - 166.

Blau, R. (2011). Funding cuts closing book on all 62 branches in Queens library. Daily News, May 24.

Bogetoft, P. and Otto, L. (2010). Benchmarking with DEA, SFA, and R. Springer.

Cleaver, J. (2015). New Hartford library grapples with budget cuts. Utica Observer Dispatch, November 17.

Collins, A. and Halverson, R. (2010). The second educational revolution: Rethinking education in the age of technology. Journal of Computer Assisted Learning, 26(1):18-27.

Davis, A. (2015). Looming crisis: Several local libraries preparing for cuts if state budget isn't passed. The Bradford Era, December 2.

Detotto, C. and McCannon, B. C. (2017). Economic freedom and public, nonmarket institutions: evidence from criminal prosecution. Economics of Governance, 18(2):1-22.

Fischel, W. A. (2010). The congruence of american school districts with other local government boundaries: A google-earth exploration. Available at SSRN: http://ssrn.com/abstract $=967399$. 
Gazette, W. (2016). County election results from around West Virginia. WV Gazette, May 10.

Hall, J. C. (2007). Local school finance and productive efficiency: Evidence from Ohio. Atlantic Economic Journal, 35:289-301.

Hammond, C. (2002). Efficiency in the provision of public services: A data envelopment analysis of UK public library systems. Applied Economics, 34(5):649-657.

Hammond, C. J. (2009). The effect of organisational change on UK public library efficiency. International Journal of Production Economics, 121(1):286-295.

Hemmeter, J. A. (2006). Estimating public library efficiency using stochastic frontiers. Public Finance Review, 34(3):328-348.

Hoxby, C. M. (1999). The productivity of schools and other local public goods producers. Journal of Public Economics, 74(1):1-30.

Institute of Museums \& Libraries Services (2013a). http://wwww.imls.gov/sites/default/files/fast_facts_pls_fy2012.pdf. Accessed on September 20, 2015.

Institute of Museums \& Libraries Services (2013b). https://www.imls.gov/assets/1/AssetManager/FY2012 Accessed on September 20, 2015.

Kelley, A. (2015). State budget impasse forces library cuts. WNEP.com, December 8.

McCallum, I. and Quinn, S. (2004). Valuing libraries. The Australian Library Journal, $53(1): 55-69$.

Ostrom, V., Tiebout, C. M., and Warren, R. (1961). The organization of government in metropolitan areas: A theoretical inquiry. American Political Science Review, $55(4): 831-842$.

Sharma, K. R., Leung, P., and Zane, L. (1999). Performance measurement of Hawaii state public libraries: An application of data envelopment analysis. Agricultural and Resource Economics Review, 28(2).

Smith, P. C. and Street, A. (2005). Measuring the efficiency of public services: The limits of analysis. Journal of the Royal Statistical Society Series A, 168(2):401-417.

Smith, R. (2015). Cedar Rapids library board hears first suggestion on budget cuts. The Gazette, November 6.

Stepleton, I. (2015). Library will keep staff, hours intact despite cuts. Ripon Commonwealth Press, December 2. 
Vitaliano, D. F. (1997). X-inefficiency in the public sector: The case of libraries. Public Finance Review, 25(6):629-643.

Vitaliano, D. F. (1998). Assessing public library efficiency using data envelopment analysis. Annals of Public and Cooperative Economics, 69(1):107-122.

Warburton, B. (2013). Libraries around the country under budget pressure. Library Journal, June 28.

West Virginia Library Commission (2013). Public Library Funding Review. West Virginia Library Commission, Charleston.

Willes, S. (2016). Monongalia County voters favor 4 of 6 proposed levies. WAJR.com, May 11.

Witte, K. D. and Geys, B. (2011). Evaluating efficient public good provision: Theory and evidence from a generalised conditional efficiency model for public libraries. Journal of Urban Economics, 69(3):319-327.

Woods, D. (2015). Bridgeton proposes to close Cumberland County library. New Jersey, December.

Worthington, A. (1999). Performance indicators and efficiency measurement in public libraries. Australian Economic Review, 32(1):31-42. 


\section{Tables \& Figures}

Table 1: Descriptive Statistics by Governance

\begin{tabular}{|c|c|c|c|c|c|}
\hline Statistic & $\mathrm{N}$ & Mean & St. Dev. & Min & $\operatorname{Max}$ \\
\hline \multicolumn{6}{|c|}{ Panel A: City } \\
\hline Served Population & 480 & $11,639.150$ & $16,597.460$ & 467 & 104,169 \\
\hline Librarians & 480 & 2.279 & 3.362 & 0.500 & 26.650 \\
\hline Books & 480 & $37,430.770$ & $39,442.610$ & 4,801 & 196,079 \\
\hline Computer & 480 & 8.983 & 8.149 & 1 & 54 \\
\hline Hours & 480 & $2,723.463$ & $1,902.738$ & 1,300 & 10,868 \\
\hline Visits & 480 & $39,361.430$ & $58,524.970$ & 1,900 & 343,252 \\
\hline Branch & 480 & 0.083 & 0.277 & 0 & 1 \\
\hline Local MM\$ & 480 & 0.085 & 0.185 & 0.001 & 1.263 \\
\hline State $\mathrm{MM} \$$ & 480 & 0.047 & 0.069 & 0.002 & 0.440 \\
\hline Federal MM\$ & 480 & 0.001 & 0.005 & 0.000 & 0.071 \\
\hline Other MM\$ & 480 & 0.016 & 0.021 & 0.000 & 0.147 \\
\hline Special Law & 480 & 0.125 & 0.331 & 0 & 1 \\
\hline \multicolumn{6}{|c|}{ Panel B: County } \\
\hline Served Population & 320 & $22,439.080$ & $31,346.050$ & 2,236 & 181,356 \\
\hline Librarian & 320 & 3.607 & 4.596 & 0.650 & 30.000 \\
\hline Books & 320 & $58,842.680$ & $86,274.030$ & 3,256 & 533,660 \\
\hline Computers & 320 & 16.272 & 24.884 & 0 & 168 \\
\hline Hours & 320 & $4,856.472$ & $4,275.987$ & 1,560 & 22,412 \\
\hline Visits & 320 & $69,264.980$ & $147,708.500$ & 2,967 & 977,670 \\
\hline Branch & 320 & 0.469 & 0.500 & 0 & 1 \\
\hline Local MM\$ & 320 & 0.245 & 0.846 & 0.000 & 5.166 \\
\hline State MM\$ & 320 & 0.086 & 0.121 & 0.008 & 0.765 \\
\hline Federal MM\$ & 320 & 0.001 & 0.005 & 0.000 & 0.067 \\
\hline Other MM\$ & 320 & 0.026 & 0.053 & 0.001 & 0.473 \\
\hline Special Law & 320 & 0.094 & 0.292 & 0 & 1 \\
\hline \multicolumn{6}{|c|}{ Panel C: Multi-Jurisdictional } \\
\hline Served Population & 170 & $31,534.380$ & $29,445.410$ & 2,917 & 96,784 \\
\hline Librarians & 170 & 6.636 & 12.095 & 0.500 & 58.630 \\
\hline Books & 170 & $82,901.480$ & $102,845.100$ & 4,513 & 484,705 \\
\hline Computers & 170 & 15.700 & 15.205 & 3 & 72 \\
\hline Hours & 170 & $5,641.929$ & $4,762.989$ & 1,612 & 21,385 \\
\hline Visits & 170 & $109,120.600$ & $124,834.000$ & 3,004 & 486,884 \\
\hline Branch & 170 & 0.471 & 0.501 & 0 & 1 \\
\hline Local MM\$ & 170 & 0.312 & 0.482 & 0.003 & 2.144 \\
\hline State MM\$ & 170 & 0.133 & 0.136 & 0.010 & 0.542 \\
\hline Federal MM\$ & 170 & 0.009 & 0.035 & 0.000 & 0.265 \\
\hline Other MM\$ & 170 & 0.035 & 0.044 & 0.001 & 0.228 \\
\hline Special Law & 170 & 0.412 & 0.494 & 0 & 1 \\
\hline
\end{tabular}


Table 2: Inputs and Outputs for DEA

\begin{tabular}{lccccc}
\hline \hline Statistic & $\mathrm{N}$ & Mean & St. Dev. & Min & Max \\
\hline \multicolumn{7}{c}{ Panel A: Inputs } \\
Book/Pop & 970 & 3.719 & 3.304 & 0.776 & 34.719 \\
Comp/Pop & 970 & 0.001 & 0.001 & 0.000 & 0.018 \\
Librarian/Pop & 970 & 0.0002 & 0.0002 & 0.00003 & 0.002 \\
Operational Exp./Pop & 970 & 14.103 & 11.284 & 3.273 & 94.897 \\
\hline \multicolumn{7}{c}{ Panel B: Outputs } & & \\
Hours/Year-Hour & 970 & 0.450 & 0.416 & 0.148 & 2.558 \\
Visits/Pop & 970 & 3.295 & 2.480 & 0.534 & 17.013 \\
Circulation/Pop & 970 & 4.058 & 3.902 & 0.043 & 37.697 \\
Total Program/Pop & 970 & 0.014 & 0.028 & -0.0004 & 0.486 \\
\hline \hline
\end{tabular}

Table 3: Descriptive Statistics for Technical Efficiency

\begin{tabular}{lccccc}
\hline \hline State & N & Mean & St. Dev. & Min & Max \\
\hline \multicolumn{5}{c}{ Panel A: Overall } \\
TE & 970 & 0.846 & 0.176 & 0.243 & 1.000 \\
\hline \multicolumn{5}{c}{ Panel B: By Governance } \\
CI & 480 & 0.81 & 0.19 & 0.24 & 1.00 \\
CO & 320 & 0.87 & 0.17 & 0.41 & 1.00 \\
MJ & 170 & 0.89 & 0.14 & 0.47 & 1.00 \\
\hline \multicolumn{5}{c}{ Panel C: By Year } \\
2004 & 970 & 0.83 & 0.18 & 0.36 & 1.00 \\
2005 & 970 & 0.81 & 0.19 & 0.38 & 1.00 \\
2006 & 970 & 0.82 & 0.19 & 0.24 & 1.00 \\
2007 & 970 & 0.84 & 0.18 & 0.33 & 1.00 \\
2008 & 970 & 0.86 & 0.17 & 0.39 & 1.00 \\
2009 & 970 & 0.86 & 0.17 & 0.37 & 1.00 \\
2010 & 970 & 0.87 & 0.18 & 0.30 & 1.00 \\
2011 & 970 & 0.86 & 0.18 & 0.35 & 1.00 \\
2012 & 970 & 0.87 & 0.15 & 0.47 & 1.00 \\
2013 & 970 & 0.85 & 0.16 & 0.35 & 1.00 \\
\hline \hline
\end{tabular}


Table 4: Control Variables

\begin{tabular}{lccccc}
\hline \hline Statistic & $\mathrm{N}$ & Mean & St. Dev. & Min & Max \\
\hline Local MM\$ & 970 & 0.177 & 0.550 & 0.000 & 5.166 \\
State MM\$ & 970 & 0.075 & 0.107 & 0.002 & 0.765 \\
Federal MM\$ & 970 & 0.002 & 0.016 & 0.000 & 0.265 \\
Other MM\$ & 970 & 0.023 & 0.039 & 0.000 & 0.473 \\
Local \% & 970 & 0.441 & 0.201 & 0.000 & 0.904 \\
State \% & 970 & 0.419 & 0.174 & 0.049 & 0.949 \\
Federal \% & 970 & 0.006 & 0.027 & 0.000 & 0.383 \\
Other \% & 970 & 0.134 & 0.104 & 0.000 & 0.524 \\
Unemploy & 970 & 7.060 & 2.252 & 2.800 & 14.100 \\
Branch & 970 & 0.278 & 0.448 & 0.000 & 1.000 \\
IRS & 970 & 0.718 & 0.450 & 0.000 & 1.000 \\
Special Law & 970 & 0.196 & 0.397 & 0.000 & 1.000 \\
Income Per Capita MM\$ & 970 & 0.029 & 0.005 & 0.016 & 0.044 \\
City Gov. & 970 & 0.495 & 0.500 & 0.000 & 1.000 \\
County Gov. & 970 & 0.330 & 0.470 & 0.000 & 1.000 \\
Multi-Jurisdictional Gov. & 970 & 0.175 & 0.380 & 0.000 & 1.000 \\
\hline \hline
\end{tabular}


Table 5: Least Square Results

\begin{tabular}{lccc}
\hline \hline & \multicolumn{3}{c}{ Dependent variable: } \\
\cline { 2 - 4 } & \multicolumn{3}{c}{$\mathrm{TE}$} \\
& $(\mathrm{OLS})$ & $(\mathrm{FE})$ & $(\mathrm{WLS})$ \\
\hline Local MM\$ & $-0.097^{* * *}$ & $-0.047^{* *}$ & -0.044 \\
& $(0.020)$ & $(0.024)$ & $(0.023)$ \\
State MM\$ & $0.559^{* * *}$ & $0.276^{* *}$ & 0.255 \\
& $(0.113)$ & $(0.138)$ & $(0.133)$ \\
Federal MM\$ & -0.096 & 0.003 & 0.019 \\
& $(0.383)$ & $(0.327)$ & $(0.322)$ \\
Other MM\$ & $0.980^{* * *}$ & 0.186 & 0.162 \\
& $(0.253)$ & $(0.247)$ & $(0.223)$ \\
Local \% & 0.050 & -0.084 & -0.078 \\
& $(0.053)$ & $(0.058)$ & $(0.058)$ \\
State \% & $0.260^{* * *}$ & 0.081 & 0.079 \\
Federal \% & $(0.061)$ & $(0.062)$ & $(0.063)$ \\
City Gov. & $0.447^{* *}$ & 0.143 & 0.151 \\
& $(0.213)$ & $(0.176)$ & $(0.170)$ \\
MJ Gov. & $-0.025^{* *}$ & $-0.103^{* * *}$ & $-0.111^{* * *}$ \\
& $(0.011)$ & $(0.016)$ & $(0.016)$ \\
Special Law & 0.010 & -0.024 & -0.030 \\
& $(0.014)$ & $(0.020)$ & $(0.020)$ \\
\hline Observations & $-0.038^{* *}$ & $-0.160^{* * *}$ & $-0.162^{* * *}$ \\
R & $(0.015)$ & $(0.038)$ & $(0.039)$ \\
County FE & 970 & 970 & 970 \\
Year FE & 0.411 & 0.660 & 0.647 \\
\hline \hline & No & Yes & Yes \\
& No & Yes & Yes \\
\hline
\end{tabular}

Note: ${ }^{* *} \mathrm{p}<0.05 ;{ }^{* * *} \mathrm{p}<0.001$; Other controls:

Branch, Unemployment rate and dummy for increasing returns to scale library systems. We use personal income as weight in the WLS model return to scale 
Table 6: Fractional Logit Results

\begin{tabular}{|c|c|c|}
\hline & Dep. & able: TE \\
\hline & (FL1) & (FL2) \\
\hline Local MM\$ & $\begin{array}{c}-1.973^{* * *} \\
(0.580)\end{array}$ & $\begin{array}{c}-4.909^{* * *} \\
(0.884)\end{array}$ \\
\hline State MM\$ & $\begin{array}{c}8.983^{* * *} \\
(1.717)\end{array}$ & $\begin{array}{c}13.157^{* * *} \\
(2.251)\end{array}$ \\
\hline Federal MM\$ & $\begin{array}{l}-1.871 \\
(4.284)\end{array}$ & $\begin{array}{c}2.991 \\
(3.813)\end{array}$ \\
\hline Other MM\$ & $\begin{array}{c}22.700^{* * *} \\
(3.979)\end{array}$ & $\begin{array}{c}-9.377^{*} \\
(4.958)\end{array}$ \\
\hline Local \% & $\begin{array}{c}0.726 \\
(0.390)\end{array}$ & $\begin{array}{l}-0.587 \\
(0.456)\end{array}$ \\
\hline State $\%$ & $\begin{array}{c}2.739^{* * *} \\
(0.478)\end{array}$ & $\begin{array}{c}0.394 \\
(0.561)\end{array}$ \\
\hline Federal \% & $\begin{array}{l}3.904^{* *} \\
(1.618)\end{array}$ & $\begin{array}{c}0.595 \\
(1.358)\end{array}$ \\
\hline City Gov. & $\begin{array}{c}-0.179^{* *} \\
(0.076)\end{array}$ & $\begin{array}{c}-0.635^{* * *} \\
(0.107)\end{array}$ \\
\hline MJ Gov. & $\begin{array}{c}0.081 \\
(0.105)\end{array}$ & $\begin{array}{c}-0.466^{* * *} \\
(0.165)\end{array}$ \\
\hline Special Law & $\begin{array}{l}-0.074 \\
(0.102)\end{array}$ & $\begin{array}{c}-0.754^{* * *} \\
(0.241)\end{array}$ \\
\hline County FE & No & Yes \\
\hline Year FE & No & Yes \\
\hline Observations & 970 & 970 \\
\hline
\end{tabular}

Note: ${ }^{* *} \mathrm{p}<0.05 ;{ }^{* * *} \mathrm{p}<0.001$

Other controls: Branch, Unemployment rate and dummy for IRS library systems. 
Appendix 1: Average TE by Library

\begin{tabular}{|c|c|c|c|c|c|}
\hline Name & Gov & AvgTE & Name & Gov & AvgTE \\
\hline ALDERSON & CI & 0.83 & MOUNDSVILLE-MARSHALL COUNTY & MJ & 0.95 \\
\hline BELINGTON & CI & 0.87 & MOUNTAINTOP & MJ & 0.63 \\
\hline BOLIVAR-HARPERS FERRY & MJ & 0.88 & NEW MARTINSVILLE & CI & 0.70 \\
\hline BOONE-MADISON & MJ & 0.88 & NITRO & CI & 1.00 \\
\hline BRIDGEPORT & $\mathrm{CI}$ & 1.00 & NUTTER FORT & CI & 0.51 \\
\hline BROOKE COUNTY & $\mathrm{CO}$ & 0.92 & OHIO COUNTY & $\mathrm{CO}$ & 1.00 \\
\hline BUFFALO CREEK MEMORIAL & CI & 0.93 & PADEN CITY & CI & 0.70 \\
\hline BURNSVILLE & CI & 0.76 & PARKERSBURG/WOOD CO. & MJ & 0.98 \\
\hline CABELL COUNTY & MJ & 1.00 & PAW PAW & CI & 0.64 \\
\hline CALHOUN COUNTY & $\mathrm{CO}$ & 0.77 & PENDLETON COUNTY & $\mathrm{CO}$ & 0.96 \\
\hline CAPON BRIDGE & CI & 0.68 & PETERSTOWN & CI & 0.91 \\
\hline CHAPMANVILLE & CI & 0.76 & PHILIPPI & CI & 0.81 \\
\hline CHARLES W. GIBSON & CI & 0.87 & PIEDMONT & CI & 0.84 \\
\hline CLARKSBURG-HARRISON CO. & MJ & 1.00 & PINE GROVE & CI & 0.84 \\
\hline CLAY COUNTY & $\mathrm{CO}$ & 0.94 & PIONEER MEMORIAL & $\mathrm{CO}$ & 0.73 \\
\hline COWEN & CI & 0.92 & PLEASANTS COUNTY & $\mathrm{CO}$ & 0.72 \\
\hline CRAFT MEMORIAL & CI & 1.00 & POCAHONTAS COUNTY & $\mathrm{CO}$ & 1.00 \\
\hline CRAIGSVILLE & $\mathrm{CO}$ & 0.92 & PRINCETON & CI & 0.98 \\
\hline DODDRIDGE COUNTY & $\mathrm{CO}$ & 0.50 & PUTNAM COUNTY & $\mathrm{CO}$ & 1.00 \\
\hline DORA BEE WOODYARD MEMORIAL & $\mathrm{CO}$ & 0.52 & RAINELLE & CI & 0.88 \\
\hline ELKINS-RANDOLPH & MJ & 1.00 & RALEIGH COUNTY & MJ & 1.00 \\
\hline FAYETTE COUNTY & $\mathrm{CO}$ & 1.00 & RICHWOOD & CI & 0.78 \\
\hline FIVE RIVERS & $\mathrm{CI}$ & 0.52 & RITCHIE COUNTY & $\mathrm{CO}$ & 0.84 \\
\hline GASSAWAY & $\mathrm{CI}$ & 0.96 & ROANE COUNTY & $\mathrm{CO}$ & 1.00 \\
\hline GILMER & CI & 0.69 & RONCEVERTE & CI & 0.74 \\
\hline GRANT COUNTY & $\mathrm{CO}$ & 0.51 & RUPERT & CI & 0.77 \\
\hline GREENBRIER COUNTY & CI & 0.96 & SHEPHERDSTOWN & CI & 1.00 \\
\hline HAMLIN-LINCOLN COUNTY & CI & 0.91 & SISTERSVILLE & MJ & 0.70 \\
\hline HAMPSHIRE COUNTY & $\mathrm{CO}$ & 0.97 & SOUTH CHARLESTON & CI & 1.00 \\
\hline HARDY COUNTY & MJ & 0.68 & SOUTH JEFFERSON & $\mathrm{CO}$ & 1.00 \\
\hline HELVETIA & $\mathrm{CO}$ & 0.85 & SOUTHERN AREA & CI & 0.66 \\
\hline HUNDRED & MJ & 1.00 & SUMMERS COUNTY & $\mathrm{CO}$ & 0.95 \\
\hline JACKSON COUNTY & $\mathrm{CO}$ & 1.00 & SUMMERSVILLE & CI & 0.79 \\
\hline KANAWHA COUNTY & $\mathrm{CO}$ & 1.00 & SUTTON & CI & 0.85 \\
\hline KEYSER-MINERAL COUNTY & MJ & 0.87 & SWANEY MEMORIAL & CI & 0.56 \\
\hline KINGWOOD & CI & 0.94 & TAYLOR COUNTY & MJ & 0.92 \\
\hline LOGAN AREA & $\mathrm{CO}$ & 0.89 & TERRA ALTA & CI & 1.00 \\
\hline LOUIS BENNETT & $\mathrm{CO}$ & 1.00 & TYGART VALLEY & CI & 0.70 \\
\hline LOWE & $\mathrm{CI}$ & 0.51 & TYLER COUNTY & CI & 0.77 \\
\hline LYNN MURRAY MEMORIAL & $\mathrm{CI}$ & 0.90 & UPSHUR COUNTY & $\mathrm{CO}$ & 0.79 \\
\hline MARION COUNTY & MJ & 0.99 & VALLEY HEAD & $\mathrm{CO}$ & 0.75 \\
\hline MARTINSBURG-BERKELEY CO. & CI & 0.94 & VIENNA & MJ & 0.81 \\
\hline MARY H. WEIR & CI & 0.40 & WAR & CI & 0.85 \\
\hline MASON COUNTY & $\mathrm{CO}$ & 0.86 & WAYNE COUNTY & $\mathrm{CO}$ & 1.00 \\
\hline MCDOWELL & $\mathrm{CI}$ & 1.00 & WEBSTER-ADDISON & MJ & 0.83 \\
\hline MINGO COUNTY & $\mathrm{CO}$ & 1.00 & WHITE SULPHUR SPRINGS & CI & 0.92 \\
\hline MONROE COUNTY & $\mathrm{CO}$ & 0.81 & WILLIAMSON & CI & 0.52 \\
\hline MORGAN COUNTY & $\mathrm{CO}$ & 0.73 & WYOMING COUNTY & $\mathrm{CO}$ & 0.95 \\
\hline MORGANTOWN & CI & 1.00 & & & \\
\hline
\end{tabular}

